\title{
IMPACT OF MALNUTRITION ON IMMUNITY AND INFECTION
}

\section{França TGD (1), Ishikawa LLW (1), Zorzella-Pezavento SFG (1), Chiuso- Minicucci F (1), da Cunha MLRS (1), Sartori A (1)}

(1) Department of Microbiology and Immunology, Botucatu Biosciences Institute, São Paulo State University, UNESP, Botucatu, São Paulo State, Brazil.

ABSTRACT: Malnutrition may be a consequence of energy deficit or micronutrient deficiency. It is considered the most relevant risk factor for illness and death, particularly in developing countries. In this review we described the magnitude of this problem, as well as its direct effect on the immune system and how it results in higher susceptibility to infections. A special emphasis was given to experimental models used to investigate the relationship between undernutrition and immunity. Malnutrition is obviously a challenge that must be addressed to health authorities and the scientific community.

KEY WORDS: malnutrition, infection, immunity, experimental models.

CONFLICTS OF INTEREST: There is no conflict.

\section{CORRESPONDENCE TO:}

ALEXANDRINA SARTORI, Departamento de Microbiologia e Imunologia, Instituto de Biociências, UNESP, Distrito de Rubião Júnior, s/n, Botucatu, SP, 18.618-000, Brazil. Phone: +55 $14 \quad 3811$ 6240. Fax: +55 $14 \quad 3811$ 6058. Email: sartori@ibb.unesp.br. 


\section{INTRODUCTION}

Malnutrition can be a consequence of energy deficit (protein-energy malnutrition PEM) or a micronutrient deficiency. In any case, it is still a major burden in developing countries and is considered the most relevant risk factor for illness and death, affecting particularly hundreds of millions of pregnant women and young children (1). This direct relationship between malnutrition and death is mainly due to the resulting immunodeficiency and, consequently, greater susceptibility to infectious agents.

It is estimated that 852 million people were undernourished between 2000 and 2002, with most (815 million) living in developing countries, particularly in southern Asia and sub-Saharan Africa (2-4).

Malnutrition by itself can cause death; however, epidemiological data reveal that it greatly increases susceptibility to and severity of infections, and is a major cause of illness and death concomitant with numerous diseases (5-7). It is the direct cause of about 300,000 deaths per year and indirectly responsible for about half of all deaths in young children (8). A direct correlation between a higher degree of malnutrition and higher risk of death is supported by the observation that severely malnourished children experience substantially higher mortality risk $(9,10)$.

Many factors affect the degree and distribution of PEM and micronutrient deficiency around the world, with poverty being at the top of the list. Other factors, in which the relationship between cause and consequence is hard to establish, are also deeply involved in malnutrition including: socioeconomic and political instability; impaired educational development; unsanitary conditions; poor food practices; breast-feeding habits and the shortage or ineffectiveness of nutrition programs $(1,11)$.

The causal relationship of malnutrition with immune suppression and infection is also aggravated by the profound effect of many infections on nutrition itself. For example, gastrointestinal parasites can lead to diarrhea, anemia and nutrient deprivation (12, 13). It is also well established that Aids, tuberculosis and other chronic infections cause cachexia and anemia $(12,14)$.

PEM is defined, in children, by measures that fall more than two standard deviations below the normal weight relative to age (underweight), the normal height relative to age (stunting) and weight for height (wasting). Among children aged less than 5 years in developing countries, about $31 \%$ are underweight, $38 \%$ have stunted growth and $9 \%$ show wasting (1). Severe malnutrition occurs almost exclusively in children 
and manifests as marasmus (severe wasting) marasmic kwashiorkor (severe wasting with edema) and kwashiorkor (malnutrition with edema) (15). Marasmus is diagnosed when subcutaneous fat and muscle are lost because of endogenous mobilization of all available energy and nutrients. Clinical aspects include a triangular face, primary or secondary amenorrhea, extended abdomen and anal or rectal prolapse (16). Kwashiorkor usually manifests as edema, changes in hair and skin color, anemia, hepatomegaly, lethargy, severe immunodeficiency and early death $(17,18)$.

Severe PEM is typically characterized by the occurrence of fat degeneration in diverse organs including the liver and heart. In the heart, it causes subclinical or even overt cardiac insufficiency that demands urgent correction. The loss of subcutaneous fat, which markedly reduces bodily capacity to regulate temperature and also to store water, can also occur, provoking dehydration, hypothermia and hypoglycemia (1921). Moreover, PEM is associated with atrophy of the small intestine that triggers the loss of both absorption and digestion capacity $(22,23)$.

\section{MALNUTRITION AFFECTS IMMUNITY}

A condition that results from a genetic or developmental defect in the immune system is called a primary immunodeficiency. Secondary or acquired immunodeficiency is the loss of immune function that results from a variety of extrinsic factors. The most well known secondary immunodeficiency is caused by the human immunodeficiency virus (HIV) infection; however, the most prevalent cause of immunodeficiency worldwide is severe malnutrition, which affects as much as $50 \%$ of the population in some impoverished communities (24). The consequent abnormalities of the immune system affect both the innate and adaptive immunity.

From a practical point of view, it is impossible to separate innate and specific arms of immunity because they work in an intrinsically connected manner in the body. However, for the sake of clarity, we will first refer to some mechanisms considered innate, i.e., the ones used against any type of pathogen. For example, availability of complement components and phagocyte function are compromised during malnutrition, which will directly affect pathogen elimination. This happens since the complement system by itself can destroy bacteria or viruses or because complement receptors present on the phagocyte surface mediate capture of pathogens. Significantly lower levels of complement, especially C3 that is the main opsonic 
component, were described by Sakamoto et al. (25). In addition, phagocyte ability to ingest and kill pathogens was also reduced (26).

Antigen-presenting cells (APC) play a cardinal role during the induction, regulation and maintenance of innate and acquired immune responses (27). A series of studies demonstrated that the biological function of different cell types (B lymphocytes, macrophages and Kupffer cells) is clearly decreased during nutritional deficiencies (28-31).

The most relevant immunological alterations found in humans or in experimental malnutrition models that affect mechanisms associated with adaptative immunity will be briefly described below. Severe protein malnutrition in newborns and infants is clearly associated with atrophy in the so called primary lymphoid organs, i.e., bone marrow and thymus. Consequences are devastating because these organs are generators of $B$ and $T$ cell repertoires. Furthermore, malnutrition clearly affects hematopoiesis, determining anemia, leucopenia and severe reduction in bone marrow. Production of IL-6 and TNF- $\alpha$ by bone marrow cells is also significantly lower in malnourished animals (32). The capacity of malnourished hematopoietic stroma to support the growth of hematopoietic stem cells (CD34+) in vitro is also decreased (33). This is a very relevant finding because CD34+ cells are able to generate multiple lymphohematopoietic lineages as myeloid, erythroid and lymphoid (B and T) (34).

Severe protein malnutrition, mainly in newborns and small children, also provokes thymus atrophy that, in turn, reduces thymus cell number and also severely affects the development of peripheral lymphoid organs (35). The immediate consequence of this atrophy is leucopenia, decreased CD4/CD8 ratio and increased number of immature T cells in the periphery. Recently, Cortés-Barberena et al. (36) observed that significant lower numbers of CD3+ lymphocytes were present in the spleen of moderately and severely malnourished rats. They also detected a considerable impairment of $\mathrm{T}$ cell activation characterized by decreased expression of CD25 and CD71 in these cells.

These disturbances in the thymus have been more intensely investigated in malnutrition experimental models. For example, it has been demonstrated that the patent atrophy is due to decrease in $\mathrm{T}$ cell proliferation and increased depletion by apoptosis, affecting mainly immature TCD4+ and TCD8+ cells. This has been, at least partially, attributed to lower leptin levels during starvation or malnutrition (37, 
35). Morphological changes in thymic epithelial cells associated with decreased thymic hormone production have also been described during malnutrition. This feature is apparently connected with a hormonal imbalance, involving a decrease in leptin and a consequent increase in glucocorticoid hormone levels in serum.

Immune responses from the epithelial barrier are also deeply affected by malnutrition. These alterations are mainly characterized by changes in the architecture of gut mucosa including flattened hypotrophia microvilli, reduced lymphocyte counts in Peyer's patches and reduced immunoglobulin A secretion (38, 39).

In our experience, BALB/c mice submitted to dietary restriction ( $80 \%$ of the amount of food consumed by a control group) during 40 days showed similar alterations. Together with a significant loss of body and spleen weights (Figure 1), these animals also presented modifications in the lymphoid organs (Figure 2). By comparison with the normal thymus presented in Figure $2 \mathrm{a}$, a severe atrophy was observed in this organ in malnourished animals. Furthermore, the distinction between cortical and medullar areas was lost in the dietary restricted group (Figure 2b). Striking changes were also observed in mucous membrane associated with small intestine. Besides being smaller and irregular, intestinal villi also lost their brush borders. These alterations can be observed in Figure $2 d$, compared to the normal correspondent structures shown in Figure 2c.

A

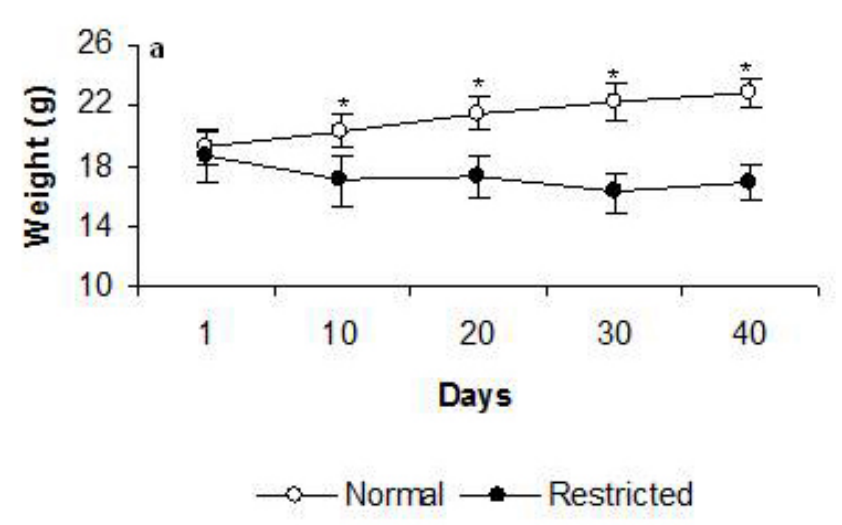

B

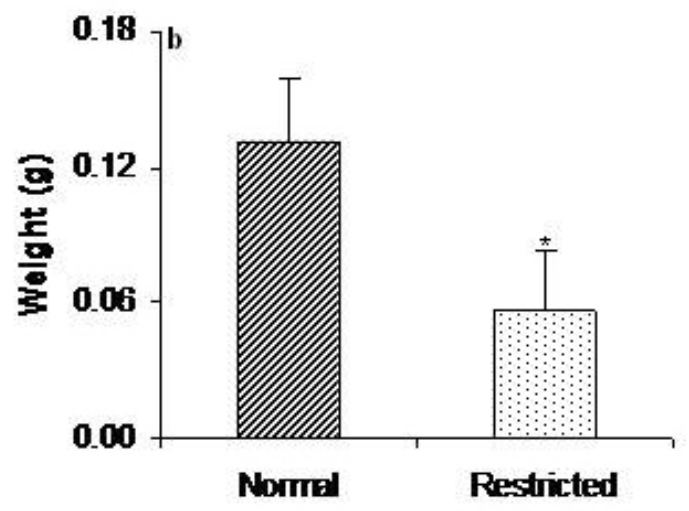

Figure 1. Effect of dietary restriction on body $(\mathbf{A})$ and spleen (B) weights. Body weight was measured every day, each group included eight mice. Spleen weight was measured only on the $40^{\text {th }}$ day after the beginning of dietary restriction; the normal group included four mice and the restricted one included three.

${ }^{*}$ Mean value was significantly different from the normal group $(p<0.05)$. 


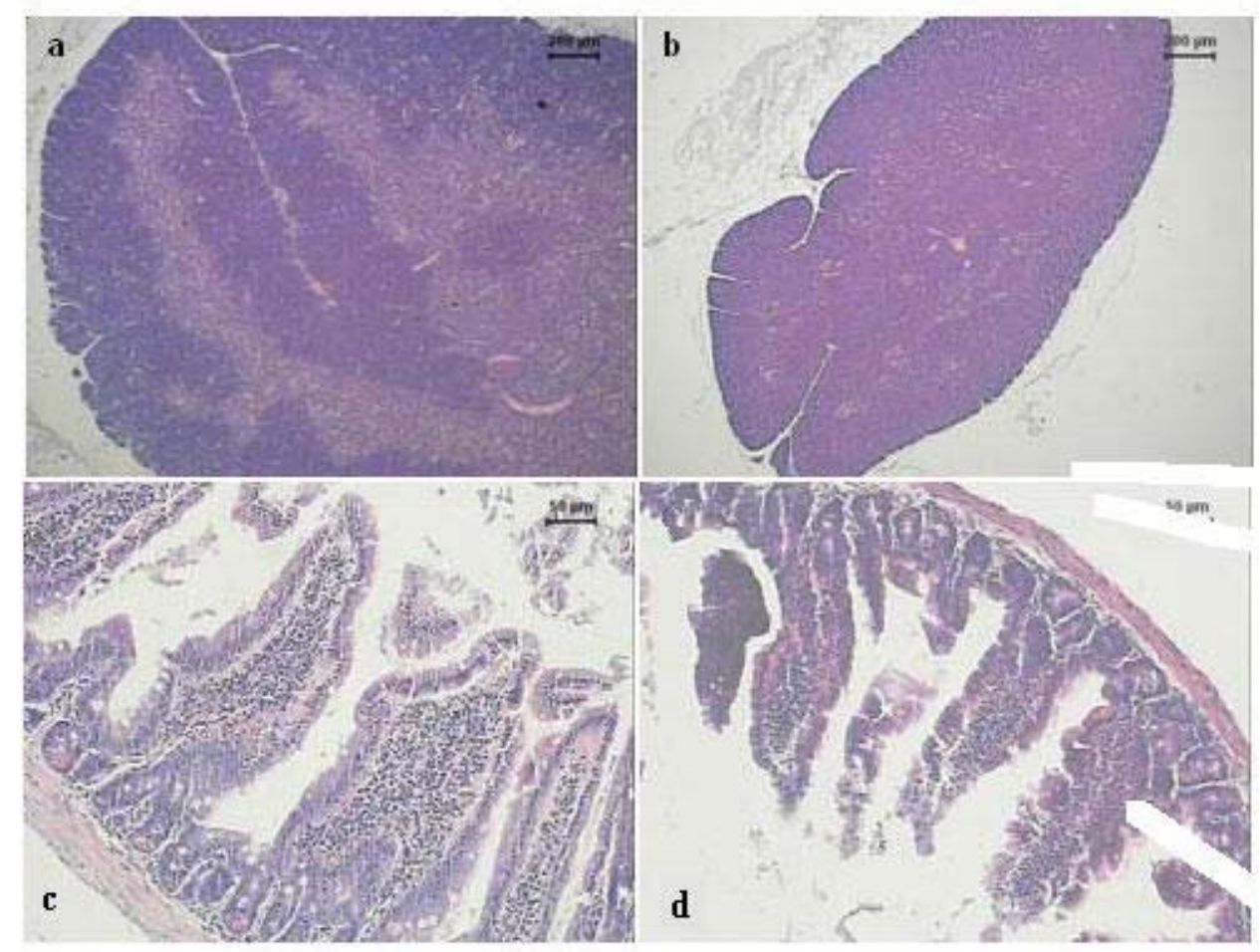

Figure 2. Effect of dietary restriction on the thymus ( $\mathbf{a}$ and $\mathbf{b}$ ) and small intestine (c and d) architecture. BALB/c mice were fed a normal diet (left column) or $80 \%$ of normal diet (right column). Sections were obtained 40 days after and stained with hematoxylin and eosin.

Antigen presentation to $T$ cells is a fundamental event that precedes the development of both humoral and cellular immunity. Three different cell types (B lymphocytes, macrophages and dendritic cells) have been described as the main APC. Among them, only dendritic cells (DC) have been more thoroughly studied during malnutrition. There is a general consensus that different aspects of $D C$ as number, cytokine production and ability to trigger proliferation of antigen-specific memory $T$ lymphocytes are significantly affected by undernutrition (40). Very recently, it was demonstrated that adoptively transferred DC were also able to restore primary cell-mediated inflammatory competence to acutely malnourished weanling mice (41). There is a general agreement that deficits of protein, energy or even both, produce a profound depression in acquired cell-mediated immune competence, whereas humoral competence is less predictably affected. This was supported by the observation that Th2-type immunoglobulins (IgG1 and $\lg E$ ) were selectively elevated in weanling mice submitted to acute malnutrition, while levels of Th1-type immunoglobulins (IgG2a and IgG3) were unaffected (42). Similar and complementary 
information was obtained in a vitamin A deficiency mice model. The shortage of this vitamin at the time of initial antigen exposure significantly enhanced the development of IL-10 producing Th2 or T regulatory cells while diminishing the expression of Th1 memory cells (43). More recently, Sakai et al. (44) corroborated these findings, demonstrating that protein deficiency impairs the induction of antigen-specific $\mathrm{T}$ cell proliferation, but not the $B$ cell response in DNA immunized mice.

One of the main mechanisms that prevents or decreases immunity during undernutrition appears to be related to the activation of $\mathrm{T}$ lymphocytes. It is well established that the voltage-dependent $K(V)$ potassium channels are vital for the activation of $\mathrm{T}$ cells. Fernández et al. (45) reported a significant decrease in the $\mathrm{K}^{+}$ current and positive activation of the membrane potential by $20 \mathrm{mV}$ in T lymphocytes derived from rats with severe malnutrition. It has also been demonstrated that moderately and severely malnourished rats present lower absolute and relative numbers of CD3+ and CD4+ lymphocyte subpopulations. This was also associated with a major decrease in the expression of CD25 and CD27 that are molecules absolutely required for $\mathrm{T}$ cell activation and proliferation (36).

The impaired activation of $T$ cells has been clearly associated with deficits of cytokine production which are the main molecular mediators of immunity. This was evident in malnourished children that showed reduced production of type 1 cytokines (IL-2 and IFN- $\gamma)(46)$.

\section{MALNUTRITION INCREASES RISK OF INFECTION}

The strong relationship between malnutrition and infection was originally described by Scrimshaw et al. (47). From this framework, much investigation was done in this area and there is a total agreement among authors that mortality is significantly more elevated in undernourished child compared to healthy ones. The study by Man et al. (48), which included a large population of hospitalized Gambian children, clearly illustrated the relationship between undernourishment, characterized by lower weight relative to age, and higher mortality indexes associated with many infectious diseases.

One-third of the world's population is infected with $M$. tuberculosis, the main agent that provokes death among infectious diseases $(49,50)$. This infection is particularly influenced by undernutrition and is a major cause of morbidity and mortality in developing countries where PCM is also prevalent (51). Furthermore, malnutrition as 
an important risk for tuberculosis has also being reinforced by findings in experimental models (52). Similarly, undernutrition may also affect the clinical outcome of tuberculosis (53). A recent meta-analysis suggested that low serum vitamin $D$ levels are associated with higher risk of active tuberculosis (54). It is important to emphasize that tuberculosis is a typical condition whose evolution, characterized by a chronic inflammatory process, accentuates undernutrition and causes a typical cachexia. This has been partially attributed to IgG1 antibodies, that up-regulate TNF- $\alpha$ and IL-6 (proinflammatory cytokines), but not to IL-10 (antiinflammatory cytokines) (55). Emergence of highly virulent drug-resistant strains of M. tuberculosis has been largely attributed to a combination of poorly implemented drug regimen and coinfection with HIV. It has been suggested by Prentice et al. (56) that malnutrition may contribute to the appearance of resistant $M$. tuberculosis strains (57).

Even though effective vaccines are licensed for measles, it continues to cause death and severe disease in children worldwide. Complications from this viral infection can occur in almost every organ or system including pneumonia, croup and encephalitis. Among other factors, malnutrition and vitamin A deficiency increase complication rates (58). There is experimental evidence that vitamin A supplementation in children is associated with a reduction from 23 to $30 \%$ in mortality risk and attenuation in disease severity (59). For this reason, the World Health Organization recommends administration of an oral dose of vitamin A to children with measles that live in vitamin A deficiency areas (60).

Malnutrition and intestinal parasitism share a similar geographic distribution, with the same individuals experiencing both diseases simultaneously (61). The coexistence between undernutrition and nematode infection involves two causal pathways, malnutrition that augments susceptibility to infection and the infection itself that leads to a more accentuated undernutrition (62). Intestinal nematodes may provoke malnutrition because they cause anorexia and a variety of pathophysiological responses in the gastrointestinal tract such as vomiting, diarrhea and malabsorption. Together, these alterations deleteriously affect the host ability to get enough nutrients from the diet (63). Parasites that clearly affect the nutritional status are soil transmitted helminths, Giardia duodenalis, Entamoeba histolytica, coccidia and Schistosoma sp. (64). 
There is also a general consensus that PEM is associated with greater malaria morbidity and mortality in humans (65). Supporting this observation, controlled clinical trials of either vitamin A or zinc supplementation indicated that these nutrients can substantially reduce clinical malaria outbreaks $(66,67)$. Opinions regarding the effect of certain micronutrients, as iron, for example, are still contradictory $(68,56)$.

Noma is an opportunistic infection promoted by extreme poverty that evolves rapidly from a gingival inflammation to mutilating orofacial gangrene. Even thought it can be observed worldwide, it is much more common in sub-Saharan Africa. It results from very complex interactions among malnutrition, infection and compromised immunity, and is very frequently preceded by malaria, measles and severe necrosating ulcerative gingivitis (69).

\section{EXPERIMENTAL MODELS}

Many studies carried out in human populations from developing countries indicated important deficiencies in macronutrients (proteins, carbohydrates and fat leading to protein-energy deficiencies), micronutrients (electrolytes, minerals and vitamins leading to specific micronutrients deficiencies) or both (70-72). These works were very relevant because they permitted the identification of the most severely affected regions and consequent intervention by humanitarian organizations and local governments. However, laboratory animals have been very useful in studying the effects of different levels of malnutrition, since non-nutritional factors that affect humans can be controlled in this type of evaluation. The use of animal models in malnutrition has brought a great deal of information to molecular mechanisms involved in the higher susceptibility to infections and also to immunodeficiency secondary to undernutrition $(73,13)$.

The most employed models are adult mice and rats (outbread or isogenic) feed with reduced amount of proteins, vitamins or micronutrients. The percentage of dietary restriction varies from 10 to $70 \%$, according to different authors. As immunodeficiency associated with prepubescent malnutrition underlies a staggering burden of infection-related morbidity, acute weanling mice have also been explored to investigate the effects of malnutrition (41). More seldom, cats and dogs have also been used. More recently, transgenic and knockout mice have also been employed to better understand the mechanisms involved in higher susceptibility to infectious agents in malnourished mice $(72,74)$. 
França TGD et al. Impact of malnutrition on immunity and infection. J Venom Anim Toxins incl Trop Dis. 2009;15(3):383

These numerous animal models allowed a growing understanding and characterization of the immunological disturbances triggered by undernutrition. Some examples of the most relevant findings in this research area are presented in Table 1.

Table 1. Experimental models employed to study the effects of malnutrition on immunity and susceptibility to infection

\begin{tabular}{|c|c|c|c|}
\hline & Diet restriction & Effect & Reference \\
\hline $\begin{array}{l}\text { Human reconstituted } \\
\text { SCID mice }\end{array}$ & $\begin{array}{c}\text { Total vitamin A } \\
\text { restriction; } \\
\text { 7-day gestation period }\end{array}$ & $\begin{array}{l}\text { Impaired antibody production after } \\
\text { tetanus toxoid immunization }\end{array}$ & 74 \\
\hline BALB/c mice & $\begin{array}{c}\text { Three diets containing } \\
6,3 \text { or } 1 \% \text { protein; } 6 \\
\text { weeks }\end{array}$ & $\begin{array}{c}\text { Excessive production of PGE2 and } \\
\text { decreased levels of IL-10 and } \\
\text { nitric oxide }\end{array}$ & 75 \\
\hline Swiss-Webster mice & $\begin{array}{l}\text { Total protein restriction; } \\
1 \text { week }\end{array}$ & $\begin{array}{l}\text { Decreased PKC activity and Bcl-2 } \\
\text { protein expression, higher } \\
\text { macrophage apoptosis }\end{array}$ & 76 \\
\hline SD rats & $\begin{array}{l}\text { Total } \mathrm{Zn} \text { restriction; } \\
34 \text { weeks }\end{array}$ & $\begin{array}{l}\text { Thymus atrophy, oligospermia, } \\
\text { testicular atrophy and loss of } \\
\text { sperm cells and spermatocytes }\end{array}$ & 77 \\
\hline BALB/c mice & $\begin{array}{l}\text { Multinutrient restriction } \\
\text { (protein, iron and zinc); } \\
6 \text { weeks }\end{array}$ & $\begin{array}{l}12 \% \text { body weight loss, lower NF- } \\
\kappa \mathrm{B} \text { activity, decreased production } \\
\text { of TNF- } \alpha \text { and NO by macrophages }\end{array}$ & 78 \\
\hline BALB/c mice & $\begin{array}{l}\text { Total vitamin A } \\
\text { restriction } \\
2-5 \text { weeks }\end{array}$ & $\begin{array}{c}\text { Increased Th2 and T regulatory } \\
\text { cells decreased Th1 }\end{array}$ & 43 \\
\hline C57BL/6 mice & $\begin{array}{l}\text { Lower casein diet }(75 \%) ; \\
\qquad 4 \text { weeks }\end{array}$ & $\begin{array}{c}\text { Impaired T cell response to DNA } \\
\text { vaccination }\end{array}$ & 44 \\
\hline Swiss mice & $\begin{array}{l}\text { PEM } \\
4 \% \text { protein }\end{array}$ & $\begin{array}{l}20 \% \text { body weigth loss, anemia, } \\
\text { leucopenia and severe reduction } \\
\text { in bone marrow, lower production } \\
\text { of TNF- } \alpha \text {, IL-1 } \alpha \text {, IL- } 6\end{array}$ & 32 \\
\hline C57BL/6 mice & $\begin{array}{l}\text { Total dietary restriction } \\
\quad(70 \%) ; 52 \text { weeks }\end{array}$ & $\begin{array}{c}\text { Decreased humoral response to } \\
\text { hepatitis B virus }\end{array}$ & 79 \\
\hline
\end{tabular}




\section{REFERENCES}

1. Müller $\mathrm{O}$, Krawinkel M. Malnutrition and health in developing countries. Can Med Assoc J. 2005;173(3):279-86.

2. Schofield C, Ashworth A. Why have mortality rates for severe malnutrition remained so high? Bull World Health Organ. 1996;74(2):223-9.

3. World Health Organization. World health report. Geneva: The Organization; 2002.

4. Food and Agriculture Organization of the United Nations. Undernourishment around the world. In: The state of food insecurity in the world 2004. Rome: The Organization; 2004.

5. Stephen CA, Thame MM, Gray R, Barker D, Wilks R, Forrester TE, McKenzie CA. Primary malnutrition. Can we always tell? West Indian Med J. 2002;51(3):148-52.

6. Rice AL, Sacco L, Hyder A, Black RE. Malnutrition as an underlying cause of childhood deaths associated with infectious diseases in developing countries. Bull World Health Organ. 2000;78(10):1207-21.

7. Black R. Micronutrient deficiency: an underlying cause of morbidity and mortality. Bull World Health Organ. 2003;81(2):79.

8. Black RE, Morris SS, Bryce J. Where and why are 10 million children dying every year? Lancet. 2003;361(9376):2226-34.

9. Chen LC, Chowdhury A, Huffman SL. Anthropometric assessment of energyprotein malnutrition and subsequent risk of mortality among preschool aged children. Am J Clin Nutr. 1980;33(8):1836-45.

10. Van Den Broeck J, Eeckels R, Vuylsteke J. Influence of nutritional status on child mortality in rural Zaire. Lancet. 1993;341(8859):1491-5.

11. Schaible UE, Kaufmann SH. Malnutrition and infection: complex mechanisms and global impacts. PLoS Med. 2007;4(5):115.

12. Agarwal D, Chakravarty J, Sundar S, Gupta V, Bhatia BD. Correlation between clinical features and degree of immunosuppression in HIV infected children. Indian Pediatr. 2008;45(2):140-3.

13. Katona $P$, Katona-Apte J. The interaction between nutrition and infection. Clin Infect Dis. 2008;46(10):1582-8.

14. Chong VH. Hepatobiliary tuberculosis: a review of presentations and outcomes. South Med J. 2008;101(4):356-61.

15. Williams CD, Oxon BM, Lond H. Kwashiorkor: a nutritional disease of children associated with a maize diet. 1935. Bull World Health Organ. 2003;81(12): 912-3. 
16. Bhan MK, Bhandari N, Bahl R. Management of the severely malnourished child: perspective from developing countries. Br Med J. 2003;326(7381):146-51.

17. Phillips RJ, Crock CM, Dillon MJ, Clayton PT, Curran A, Harper JI. Cystic fibrosis presenting as kwashiorkor with florid skin rash. Arch Dis Child. 1993;69(4):446-8.

18. Oumeish OY, Oumeish I. Nutritional skin problems in children. Clin Dermatol. 2003;21(4):260-3.

19. Sakurada S, Shido O, Sugimoto N, Hiratsuka Y, Yoda T, Kanosue K. Autonomic and behavioural thermoregulation in starved rats. J Physiol. 2000;526 Pt 2:417-24.

20. Alam NH, Hamadani JD, Dewan N, Fuchs GJ. Efficacy and safety of a modified oral rehydration solution (ReSoMaL) in the treatment of severely malnourished children with watery diarrhea. J Pediatr. 2003;143(5):614-9.

21. De Mello MA, Luciano E, Carneiro EM, Latorraca MQ, Machado de Oliveira CA, Boschero AC. Glucose homeostasis in pregnant rats submitted to dietary protein restriction. Res Commun Mol Pathol Pharmacol. 2003;113-114:229-46.

22. Lenaerts K, Sokolović M, Bouwman FG, Lamers WH, Mariman EC, Renes J. Starvation induces phase-specific changes in the proteome of mouse small intestine. J Proteome Res. 2006;5(9):2113-22.

23. Vidueiros SM, Fernandez I, Slobodianik N, Roux ME, Pallaro A. Nutrition disorder and immunologic parameters: study of the intestinal villi in growing rats. Nutrition. 2008;24(6):575-81.

24. Geraix J, Carvalhaes MABL, Pereira PCM. Different nutritional-state indicators of HIV-positive individuals undergoing antiretroviral therapy. J Venom Anim Toxins incl Trop Dis. 2008;14(2):338-56.

25. Sakamoto M, Fujisawa Y, Nishioka K. Physiologic role of the complement system in host defense, disease, and malnutrition. Nutrition. 1998;14(4):391-8.

26. Chandra RK. Nutrition and the immune system from birth to old age. Eur J Clin Nutr. 2002;56 Suppl 3:S73-6.

27. Mellman I, Steinman RM. Dendritic cells: specialized and regulated antigen processing machines. Cell. 2001;106(3):255-8.

28. Redmond HP, Shou J, Kelly CJ, Schreiber S, Miller E, Leon P, Daly JM. Immunosuppressive mechanisms in protein-calorie malnutrition. Surgery. 1991;110(2):311-7. 
29. Petro TM, Schwartz KM, Chen SSA. Production of IL2 and IL3 in syngeneic mixed lymphocyte reactions of BALB/c mice are elevated during a period of moderate dietary protein deficiency. Immunol Invest. 1994;23(2):143-52.

30. Honda M, Kamiyama Y, Kawamura K, Kawahara K, Shishido S, Nakai H, Kawamura T, Ito H. Growth, development and nutritional status in Japanese children under 2 years on continuous ambulatory peritoneal dialysis. Pediatr Nephrol. 1995;9(5):543-8.

31. Stapleton PP, Fujita J, Murphy EM, Naama HA, Daly JM. The influence of restricted calorie intake on peritoneal macrophage function. Nutrition. 2001;17(1):415.

32. Fock RA, Vinolo MA, de Moura Sá Rocha V, de Sá Rocha LC, Borelli P. Proteinenergy malnutrition decreases the expression of TLR-4/MD-2 and CD14 receptors in peritoneal macrophages and reduces the synthesis of TNF-alpha in response to lipopolysaccharide (LPS) in mice. Cytokine. 2007;40(2): 105-14.

33. Xavier JG, Favero ME, Vinolo MAR, Rogero MM, Dagli MLZ, Arana-Chavez VE, Borojevic R, Borelli P. Protein-energy malnutrition alters histological and ultrastructural characteristics of the bone marrow and decreases haematopoiesis in adult mice. Histol Histopathol. 2007;22(4-6):651-60.

34. Giassi LJ, Pearson T, Shultz LD, Laning J, Biber K, Kraus M, et al. Expanded CD34+ human umbilical cord blood cells generate multiple lymphohematopoietic lineages in NOD-scid IL2rgamma(null) mice. Exp Biol Med (Maywood). 2008;233(8):997-1012.

35. Savino W. The thymus gland is a target in malnutrition. Eur J Clin Nutr. 2002;56 Suppl 3:S46-9.

36. Cortés-Barberena E, González-Márquez H, Gómez-Olivares JL, Ortiz-Muñiz R. Effects of moderate and severe malnutrition in rats on splenic $T$ lymphocyte subsets and activation assessed by flow cytometry. Clin Exp Immunol. 2008;152(3):585-92.

37. Ahima RS, Prabakaran D, Mantzoros C, Qu D, Lowell B, Maratos-Flier E, Flier JS. Role of leptin in the neuroendocrine response to fasting. Nature. 1996;382(6588):250-2.

38. Beisel WR. Nutrition in pediatric HIV infection: setting the research agenda. Nutrition and immune function: overview. J Nutr. 1996;126(10 Suppl):2611-5S. 
39. Souza ME. Evaluation of the intestinal microbiota of individuals injured by biological materials in occupational accidents and subjected to antiretroviral prophylaxis. J Venom Anim Toxins incl Trop Dis. 2007;13(3):694.

40. Abe M, Akbar F, Matsuura B, Horiike N, Onji M. Defective antigen-presenting capacity of murine dendritic cells during starvation. Nutrition. 2003;19(3):265-9.

41. Hillyer L, Whitley C, Olver A, Webster M, Steevels T, Woodward B. Adoptively transferred dendritic cells restore primary cell-mediated inflammatory competence to acutely malnourished weanling mice. Am J Pathol. 2008;172(2):378-85.

42. Neyestani TR, Woodward B. Blood concentrations of Th2-type immunoglobulins are selectively increased in weanling mice subjected to acute malnutrition. Exp Biol Med (Maywood). 2005;230(2):128-34.

43. Stephensen CB, Jiang $X$, Freytag $T$. Vitamin A deficiency increases the in vivo development of IL-10-positive Th2 cells and decreases development of Th1 cells in mice. J Nutr. 2004;134(10):2660-6.

44. Sakai T, Mitsuya K, Kogiso M, Ono K, Komatsu T, Yamamoto S. Protein deficiency impairs DNA vaccine-induced antigen-specific $T$ cell but not $B$ cell response in C57BL/6 mice. J Nutr Sci Vitaminol (Tokyo). 2006;52(5):376-82.

45. Fernández RG, Leehan JA, Pastrana RF, Muñiz RO. Effect of malnutrition on K+ current in T Iymphocytes. Clin Diagn Lab Immunol. 2005;12(7):808-13.

46. Rodríguez L, González C, Flores L, Jiménez-Zamudio L, Graniel J, Ortiz R. Assessment by flow cytometry of cytokine production in malnourished children. Clin Diagn Lab Immunol. 2005;12(4):502-7.

47. Scrimshaw NS, Taylor CE, Gordon JE. Interactions of nutrition and infection. Monogr Ser World Health Organ. 1968;57:3-329.

48. Man WD, Weber M, Palmer A, Schneider G, Wadda R, Jaffar S, et al. Nutritional status of children admitted to hospital with different diseases and its relationship to outcome in the Gambia, West Africa. Trop Med Int Health. 1998;3(8):678-86.

49. Flynn JL, Chan J. Immunology of tuberculosis. Annu Rev Immunol. 2001;19: 93129.

50. Young DB, Duncan K. Prospects for new interventions in the treatment and prevention of mycobacterial disease. Annu Rev Microbiol. 1995;49:641-73.

51. Udani PM. BCG vaccination in India and tuberculosis in children: newer facets. Indian J Pediatr. 1994;61(5):451-62. 
52. Cegielski JP, McMurray DN. The relationship between malnutrition and tuberculosis: evidence from studies in humans and experimental animals. Int $\mathrm{J}$ Tuberc Lung Dis. 2004;8(3):286-98.

53. Singal A, Pandhi D, Agrawal SK. Multifocal scrofuloderma with disseminated tuberculosis in a severely malnourished child. Pediatr Dermatol. 2005;22(5):440-3.

54. Nnoaham KE, Clarke A. Low serum vitamin D levels and tuberculosis: a systematic review and meta-analysis. Int J Epidemiol. 2008;37(1):113-9.

55. Hussain R, Shiratsuchi H, Phillips M, Ellner J, Wallis RS. Opsonizing antibodies (lgG1) up-regulate monocyte proinflammatory cytokines tumor necrosis factor-alpha (TNF-alpha) and IL-6 but not anti-inflammatory cytokine IL-10 in mycobacterial antigen-stimulated monocytes - implications for pathogenesis. Clin Exp Immunol. 2001;123(2):210-8.

56. Prentice AM, Gershwin ME, Schaible UE, Keusch GT, Victora CG, Gordon JI. New challenges in studying nutrition: disease interactions in the developing world. $J$ Clin Invest. 2008;118(4):1322-9.

57. Beck MA. Selenium and vitamin E status: impact on viral pathogenicity. J Nutr. 2007;137(5):1338-40.

58. Perry RT, Halsey NA. The clinical significance of measles: a review. J Infect Dis. 2004;189 Suppl 1:S4-16.

59. Oliveira JM, Rondó PH. Evidence of the impact of vitamin A supplementation on maternal and child health. Cad Saude Publica. 2007;23(11):2565-75.

60. Huiming $\mathrm{Y}$, Chaomin W, Meng M. Vitamin A for treating measles in children. Cochrane Database Syst Rev. 2005;19(4):CD001479.

61. Pelletier DL, Frongillo EA Jr, Schroeder DG, Habicht JP. A methodology for estimating the contribution of malnutrition to child mortality in developing countries. $J$ Nutr. 1994;124(10 Suppl):2106S-22S.

62. Scrimshaw NS, SanGiovanni JP. Synergism of nutrition, infection, and immunity: an overview. Am J Clin Nutr. 1997;66(2):464S-77S.

63. Koski KG, Scott ME. Gastrointestinal nematodes, nutrition and immunity: breaking the negative spiral. Annu Rev Nutr. 2001;21:297-321.

64. Hesham MS, Edariah $A B$, Norhayati M. Intestinal parasitic infections and micronutrient deficiency: a review. Med J Malaysia. 2004;59(2):284-93.

65. Shankar AH. Nutritional modulation of malaria morbidity and mortality. J Infect Dis. 2000;182 (Suppl 1):S37-53. 
66. Caulfield LE, Richard SA, Black RE. Undernutrition as an underlying cause of malaria morbidity and mortality in children less than five years old. Am J Trop Med Hyg. 2004;71(2 Suppl):55-63.

67. Enwonwu CO, Falkler WA Jr, Phillips RS. Noma (cancrum oris). Lancet. 2006; 368(9530):147-56.

68. Millward DJ, Jackson AA. Protein/energy ratios of current diets in developed and developing countries compared with a safe protein/energy ratio: implications for recommended protein and amino acid intakes. Public Health Nutr. 2004;7(3):387405.

69. Cunningham-Rundles S, McNeeley DF, Moon A. Mechanisms of nutrient modulation of the immune response. J Allergy Clin Immunol. 2005;115(6): 1119-28.

70. Grossniklaus DA, O'Brien MC, Clark PC, Dunbar SB. Nutrient intake in heart failure patients. J Cardiovasc Nurs. 2008;23(4):357-63.

71. Wintergerst ES, Maggini S, Hornig DH. Contribution of selected vitamins and trace elements to immune function. Ann Nutr Metab. 2007;51(4): 301-23.

72. Waters WR, Palmer MV, Nonnecke BJ, Whipple DL, Horst RL. Mycobacterium bovis infection of vitamin D-deficient NOS2-/-mice. Microb Pathog. 2004;36(1):11-7.

73. Chatraw JH, Wherry EJ, Ahmed R, Kapasi ZF. Diminished primary CD8 T cell response to viral infection during protein energy malnutrition in mice is due to changes in microenvironment and low numbers of viral-specific CD8 T cell precursors. J Nutr. 2008;138(4):806-12.

74. Molrine DC, Polk DB, Ciamarra A, Phillips N, Ambrosino DM. Impaired human responses to tetanus toxoid in vitamin A-deficient SCID mice reconstituted with human peripheral blood lymphocytes. Infect Immun. 1995;63(8):2867-72.

75. Anstead GM, Chandrasekar B, Zhao W, Yang J, Perez LE, Melby PC. Malnutrition alters the innate immune response and increases early visceralization following Leishmania donovani infection. Infect Immun. 2001;69(8):4709-18.

76. Rivadeneira DE, Grobmyer SR, Naama HA, Mackrell PJ, Mestre JR, Stapleton PP, et al. Malnutrition-induced macrophage apoptosis. Surgery. 2001;129:617-25.

77. Nodera M, Yanagisawa $\mathrm{H}$, Wada O. Increased apoptosis in a variety of tissues of zinc-deficient rats. Life Sci. 2001;69:1639-49. 
França TGD et al. Impact of malnutrition on immunity and infection. J Venom Anim Toxins incl Trop Dis. 2009;15(3):390

78. Anstead GM, Chandrasekar B, Zhang Q, Melby PC. Multinutrient undernutrition dysregulates the resident macrophage proinflammatory cytokine network, nuclear factor-kappa-B activation, and nitric oxide production. J Leukoc Biol. 2003;74(6):98291.

79. Niiya T, Akbar SM, Yoshida O, Miyake T, Matsuura B, Murakami H, et al. Impaired dendritic cell function resulting from chronic undernutrition disrupts the antigen-specific immune response in mice. J Nutr. 2007;137:671-5. 